\title{
THE EFFECT OF LENGTH TIME IN USING POLYAMIDE NETS (PA) MULTIFILAMENT SIZE 210D/15 MESH SIZE $3 / 4$ INCH ON THE PART OF THE PURSE SEINE NETS TO THE VALUE OF BREAKING STRENGTH AND ELONGATION
}

\author{
Azzahra Tiara Citra, Boesono S. Herry, Jayanto Bogi Budi* \\ University of Diponegoro, Semarang, Indonesia \\ *E-mail: bogipsp002@gmail.com
}

\begin{abstract}
Fishing gear consists of natural materials (natural fibres) and synthetic materials (synthetic fibres). The advantage of using synthetic materials is more durable. Polyamide is one of the examples of synthetic materials or also known as nylon. The effectiveness of the material makes fishermen not spend much money on the treatment of fishing gear. It is necessary to consider all aspects that affect the stability to achieve high elasticity, such as breaking strength and elongation. The method of this study was descriptive analysis which refers to the SNI ISO 1806:2010 method. Data were collected in dry conditions with nets as a sample and $3,6,9,12$ months of the length time of net usage, and one sample fishing gear that has not been used as a control variable. Each treatment was repeated 10 times, and then the value of breaking strength and elongation were tested by using an autograph machine. The result of this study is the value of breaking strength of multifilament polyamide (PA), net decreases alongside with length time of net usage. The value of elongation of multifilament polyamide (PA), net also decreases alongside with net usage time. There is a strong relationship between length time of net usage and the value of breaking strength and there is a strong relationship between length time of net usage and the value of elongation.
\end{abstract}

\section{KEYWORDS}

Synthetic fibre, breaking strength, elongation, fishing gear, multifilament, polyamid.

Based on the basic material, fishing gear is divided into two types; the material from natural fibres and the synthetic fibres. Nature material is made from plant fibres (cotton, manila, hemp). Synthetic material is produced through machines which the fibres is obtained from chemical processes through polymerization processes. The difference between natural fibres and synthetic fibres is in the durability. Synthesis material is better than natural material because they do not putrefaction. The Example of synthetic fibres material is Polyamide (PA), Polyethylene (PE), Polyester (PES), Polypropylene (PP), Polyvinyl Chloride (PVC), Polyvinyl Alcohol (PVA), Polyvinylidene Chloride (PVD).

In general, breaking strength and elongation is used to measure the durability of synthetic fibres. Mesh breaking strength is a maximum strength that can be held by mesh until one of the 4 vertices is loose or the yarn connecting between the 2 vertices is severed. Elongation is the addition of the yarn length to the actual length due to the tension appearance. Test that uses tension and elongation are elasticity values. The level of breaking strength and elongation is an essential part because the durability of synthetic yarn is seen from the value of breaking strength and elongation value. The high strength value of the yarn and low of the elongation will create a level of effectiveness in the material. The effectiveness of the material makes fishermen not spend much money on the treatment of fishing gear. It is necessary to consider all aspects that affect the stability to achieve the high elasticity, such as breaking strength and elongation (Hasly et al., 2017).

One of the fishing gears that uses PA (polyamide) multifilament is purse seine. A purse seine is fishing gear from nets operated by encircling a school of fish until the net is shaped like a bowl. This fishing gear is used to catch schooling pelagic fish. The way of operation the purse seine is by circling the school of fish. Pull the wrinkle rope at the bottom nets, so that the nets are shaped like a bag and trap the fish in it, then the catch is transferred to the vessel using a scoop. Improper treatment towards fishing nets (purse seine) after operating 
has a significant effect toward the resistance of fibres synthetic. Placing the fishing gear, especially net-based in the outside and exposed to sunlight directly, allows the net to experience a lowering in breaking strength. An increase in the length time of using the net and use nets continuously will lead to weathering of the yarn resulting in reduced mesh breaking strength. These conditions of length time in using purse seine are dissimilar and making durability also different. Based on the difference in durability, it is necessary to test the purse seine nets.

\section{LITERATURE REVIEW}

Synthetic fibres are better and have advantages compared to natural fibres. According to Ardidja (2010), synthetic fibres are not easily decayed due to the natural fibres not containing cellulose. Synthetic fibres are a process of chemical technology, chemical elements, or basic substance combined through a complicated process to achieve a final result. Breaking strength from the synthetic yarn is bigger than natural fibres. The absorption in synthetic fibres to the water is lower than in natural fibres because synthetic fibres have smaller cavities. Diameter of synthetic fibres able to be adjusted by the needs. In general, Synthetic fibres have an infinitesimal diameter which could minimize yarn surface area to reduce the pressure on the water toward the material. The small surface area of the yarn can reduce the pressure which makes the bigger sinking speed.

Synthetic fibres are more widely used than natural fibres as materials for making fishing gear. Synthetic has a scientific term and technique for a chemical process. It is a combination of chemical elements and amplified by the factory with the new characteristics. The basic materials of synthetic fibres are easy to find, it comprises the basic substance of chemistry materials. Therefore, the net yarn can be divided into two things; monofilament and multifilament. Monofilament means single filament. Meanwhile, multifilament is a yarn whose filaments are combined or twisted (Puspito, 2009). Synthetic fibres are rapidly evolving in replacing natural fibres in an essential component from fishing gear technology. The use of synthetic yarn increased as one of the fisheries sector development factors. The development of synthetic yarn usage still has a weakness. Synthetic fibres can still experience a decrease in terms of quality due to the natural conditions which is ultraviolet (UV) light. UV light affects the breaking strength value of synthetic fibres. Synthetic fibres have foul-resistant properties compared to natural fibres, but they tend to experience decreased strength when exposed to sunlight continuously (Al-Oufi et al., 2003).

Breaking strength is the maximum strength required to break the material in a test that uses tension, usually defined in kilogram units of force (kgf). According to Murdani et al., (2015), the value of yarn breaking strength can be seen by looking at the graph produced by the strength tester. The value of the breaking strength is shown by the needle moving on a load scale in kilogram-force (kgf). A strength tester is a special tool used to test the breaking strength of a material. Samples to be tested are attached to the hook and press the start button and the sample will be pulled until it breaks. Machines to test the breaking strength have different capabilities at maximum loads. The breaking strength unit is Kilogram Force (Kgf) or deca Newton (daN), 1 and $=1.02 \mathrm{Kgf}$ (Ramos, 1999).

Elongation is an increase in length from a test example that uses tension and is expressed in units of length $(\mathrm{cm}$ and $\mathrm{mm}$ ). In addition, elongation is an increase in length which causes the breakdown of textile fibre. The value of elongation is longer than the preserved yarn. The more liquid substances absorbed by the materials, the greater the inherent power will also increase the strength of the material. The difference between the structure of the yarn and the absorption type of different test yarns in every yarn makes elongation of test yarns different from each other. The amount of elongation depends on the level of hardness of the shortcut or density of each woven yarn (Irsyadi et al., 2015)

Augmentation of the yarn length from the actual length due to the presence of tension towards it is expressed in units of length. Permanent elongation is part of the total increase in length that remains after being freed from the tension effect stated in percent. Generally, factories declare elongation at certain loads such as breaking loads to net yarn in a dry 
condition. This condition has no relevance to fishing gear. It makes the International Organization of Standardization (ISO) recommend elongation testing, both dry and wet, at half the same value as the knot load withstanding capability (Ardidja, 2010).

Elongation is the length increase from the specimen during breaking strength testing. Elongation measurement can be done by 2 methods; manual measurement and breaking strength tester machine measurement results. Manual measurement by comparing the initial length with the length after the sample has been dropped. Measurement with breaking strength tester machines the results of elongation will be raised together with the result of breaking strength value. Elongation has a unit of a percent (\%) (Ramos, 1999).

Improper handling of fishing gear has a big effect on the durability of synthetic fibres. Placing nets and being exposed to direct sunlight might be weathering, According to Thomas and Hridayanathan (2006), weathering causes modification and damage to the molecular structure of polymers, which leads to loss of strength, extensibility, durability, and general appearance in polyamide (PA) yarns. The weakness of polyamide (PA) yarn is a high sensitivity to ultraviolet (UV) light. The well-maintained PA nets lost about $25 \%$ of its strength during the first season and another $10 \%$ during the second season. Weather tests and light exposure explain that losses in breaking strength are commonly used as a measure of the amount of degradation. The durability of both the breaking strength and the ability of the extension is a measure of the effect of solar radiation on the PA filament.

According to Fadhari et al. (2015), elongation has several factors that influence the value, include the following: yarn structure; absorbent force to water; the level of hardness of the cut.

Putting a net-based fishing gear outside and exposed to direct sunlight is a case of improper handling. Nets that are dried continuously in the outside, which is open air, will experience a decrease in breaking strength due to exposure to sunlight. According to Prasetyo and Iskandar, (2010), the breaking strength of synthetic fibres changes the breaking strength. In addition, to the influence of ultraviolet light, weather changes also affect changes in break strength of synthetic fibres. The level of reduction in breaking strength of the net yarn due to putting them up in open space depends on the type of yarn and its diameter.

\section{METHODS of RESEARCH}

This study used net mesh on the seine purse fishing gear with the same size, however, they have a different length of use of the net. 4 samples were taken from 5 vessels with a vessel size of 98 GT. These samples have a net usage time of $3,6,9$, and 12 months with polyamide (PA) multifilament material on seine purse fishing gear with yarn size 210D/15 with mesh size 3/4 inch. Other test materials were unused nets, it required samples of nets that have not been used as a standard reference for net durability value. Picture 5 is a net picture as a sample to test.

The taken sample was in the mesh size unit of the bag part on the seine purse fishing gear that has not been repaired because the bag was the part that gained a greater load compared to the other part. During the interval, the net sample was still treated as it was when the sampling was kept in the open and carried out drying in the sun. These steps were used to prepare for a dry test.

This study used the descriptive method. Research was conducted to describe the length of time using nets able to affect the durability of purse seine nets. Therefore, tests were conducted to describe and conclude how old the technical purse seine nets are. The study was conducted by looking for appropriate samples which the researcher conducted field survey to find seine purse fishing gear with a usage time of $3,6,9$, and 12 months. Sampling on mesh size units of the pockets on the seine purse fishing gear that has not been repaired. Variables that must be equalized include the type of purse seine, the size of the mesh, and the size of the yarn, as well as the brand of production nets. Sample test results were compared to unused mesh test results. Thus, the differences in test results can be seen. 


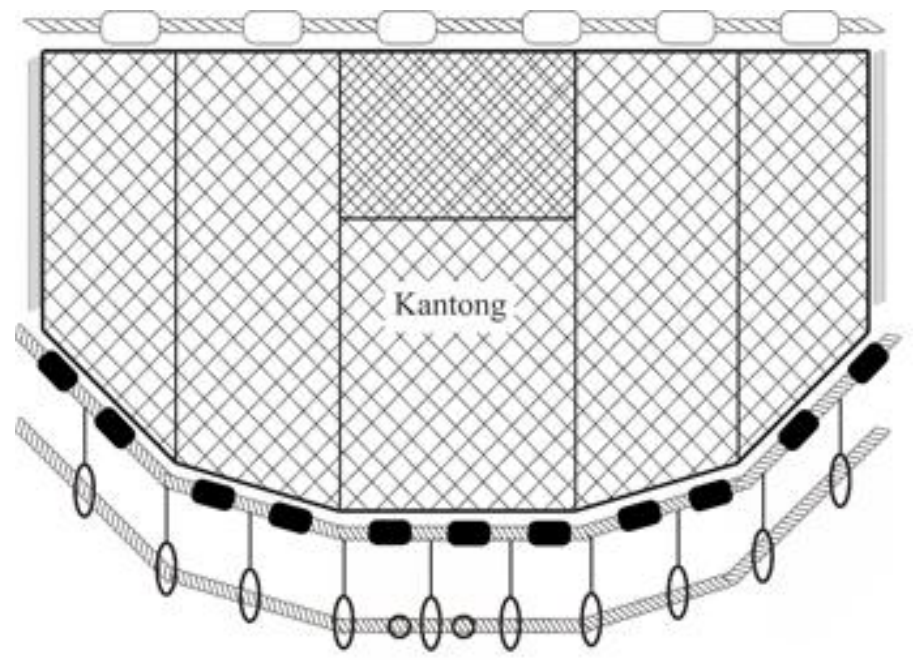

Figure 1 - Illustration of fishing gear

The testing place of yarn was in the quality control room of PT Arteria Daya Mulia with the requirements of the room including the temperature and humidity of the room by following per under SNI ISO 1806:2010. The material used net samples obtained from fishermen with polyamide (PA) multifilament material in seine purse fishing gear with yarn size 210D/15 with mesh size 3/4 inches and has different operational life. As for each treatment was done 10 repetitions by following per SNI ISO 1806:2010, at least 10 valid single tests on each package of test samples must be carried out. The next process is that the test material is taken one mesh for each test. After that, tested the value of breaking strength and elongation using the breaking strength machine and Trapezium II application.

Table 1 - Tools needed to conduct research

\begin{tabular}{|l|l|l|l|}
\hline $\begin{array}{l}\text { No } \\
.\end{array}$ & Name & Accuracy & Function \\
\hline 1. & Tecklock & $0.01 \mathrm{~mm}$ & to measure yarn diameter \\
\hline 2. & Autograph type AGS-J & $\begin{array}{l}1 \mathrm{KN} \text { (Kilogram } \\
\text { Newton) }\end{array}$ & $\begin{array}{l}\text { to measure breaking strength and netting } \\
\text { elongation }\end{array}$ \\
\hline 3. & $\begin{array}{l}\text { Computer with Trapezium II and SPSS 21 } \\
\text { Applications }\end{array}$ & - & testing machine and data processing reader \\
\hline 4. & Scissor & - & to cut samples \\
\hline 5. & Vernier calipers & $1 \mathrm{~mm}$ & to measure mesh size \\
\hline
\end{tabular}

Source: Research, 2021.

Testing yarn according to SNI ISO $1806 ; 2010$ is testing can be carried out in two situations, wet and dry, but testing in wet situations is considered more important because it is in accordance with the purpose of netting. This study used a dry test because of the standard of the machine used in PT. Arteria Daya Mulia (ARIDA) can only be used for dry testing. Wet test can only be done if the machine is recalibrated and reset for the wet test.

The research procedures used are as follows:

- Examine the distance between the locking fixtures corresponds to the size of the net mesh;

- Put in test samples in the test machine then the knots are in the right position (knots do not tap pegs);

- Implement the strength until it reaches a defined breakup time;

- If the sample does not break on any of these knots or the test connection must be discarded;

- Discarding all observations in the knots example does not break (shift) or change. The test should be retested. 
Testing using an autograph machine can produce breaking strength and elongation. The elongation of a net cannot be measured manually by comparing the starting length and the end length. It is because the net has knots and shape constructions rather than just yarnlike lengths. Testing machine using 100 force with time and temperature in accordance with SNI ISO 1806;2010 that nets must be broken when the time is 20 seconds \pm 3 seconds and room temperature 20-21C. According to Shimadzu (1999), the following procedures performed to use the autograph machine:

- Activate the breaking strength machine and the computer then operates the Trapezium II program. On the computer screen will appear a wizard method display consists of start, system, testing, specimen, data processing, chart, and finish;

- Set the gauge length in accordance with the length of the specimen to be tested;

- Put in the test material on the upper and lower load clamps, then tighten the regulator lock;

- Calibrating force and position, which aims to neutralize the test equipment then the force becomes $0 \mathrm{kgf}$ and the position becomes $0 \mathrm{~cm}$;

- Press the start button to start the machine then the cross head will move up until the yarn breaks;

- After the test material is broken, the computer will automatically read and record the results of yarn breaking strength and changes in length or elongation (stroke/displacement)

In the first aims of this study, data analysis used descriptive analysis to analyze the value of breaking strength. In the second aim of this study, data analysis used descriptive analysis, summarized data that presented in the form of Tables and graphs. Analyzed the relationship between the length of net usage toward breaking strength and elongation with an analysis tool. This study analyzed Pearson correlation test, and follow-up test to find out the extent of the influence of breaking strength and elongation on the length of time using nets with the analysis tool, namely Simple Regression Analysis Test. The process of processing data from research using SPSS software with an analysis model as follows:

Analysis Model:

- $\quad B S=a+b$ LP;

- $B S=a L P b$;

- $E=a+b$ LP;

- $E=a$ LP b.

Description: BS (breaking strength), E (elongation), LP (length of use with month). Net samples were new nets and nets that have been used by fishermen in Tegal city with the same technical specifications and decision-making rules as follows:

Knows the relationship between breaking strength and elongation with different Net Usage Length (Pearson Correlation Test) with a probability of 0.05 .

- Asymp.Sig value $>0.05$ means Ho accepted.

- Asymp.Sig value < 0.05 means Ho rejected.

Knows the influence of breaking strength and elongation with different usage lengths (Simple Regression Analysis Test) with a probability of 0.05 .

- Asymp.Sig value $>0.05$ means Ho accepted.

- Asymp.Sig value < 0.05 means Ho was rejected.

\section{RESULTS AND DISCUSSION}

Breaking strength test towards the length of time purse seine net was a test used to show the durability of fibre was breaking strength. This is because the resistance of a fishing gear material is very influential for the further fishing business. Testing breaking strength on the length of time used 5 variables. Unused nets were used as control variables and compared to those already used with a service life of 3, 6, 9, and 12 months. Testing was conducted based on SNI ISO 1806:2010. The results obtained in breaking strength testing towards the length of time using purse seine nets were found in Table 2. 
Table 2 - Breaking Strength Results

\begin{tabular}{|c|c|c|c|c|c|}
\hline \multirow{2}{*}{ No } & \multicolumn{5}{|c|}{ Breaking Strength (Kgf) } \\
\cline { 2 - 5 } & Unused & $\begin{array}{c}\text { Age } \\
\text { 3-month }\end{array}$ & $\begin{array}{c}\text { Age } \\
\text {-month }\end{array}$ & $\begin{array}{c}\text { Age } \\
\text { 9-month }\end{array}$ & $\begin{array}{c}\text { Age } \\
12 \text {-month }\end{array}$ \\
\hline 1 & 21.75 & 16.30 & 14.29 & 10.62 & 10.36 \\
\hline 2 & 19.05 & 15.55 & 14.72 & 11.66 & 9.51 \\
\hline 3 & 20.60 & 16.09 & 14.66 & 10.44 & 10.17 \\
\hline 4 & 21.41 & 16.17 & 1410 & 12.18 & 9.03 \\
\hline 5 & 20.59 & 15.47 & 12.40 & 10.78 & 8.62 \\
\hline 6 & 19.65 & 18.82 & 13.92 & 10.59 & 9.06 \\
\hline 7 & 19.96 & 16.79 & 14.67 & 10.00 & 10.65 \\
\hline 8 & 19.55 & 15.33 & 11.95 & 11.83 & 10.26 \\
\hline 9 & 19.40 & 17.99 & 13.35 & 12.01 & 10.26 \\
\hline 10 & 20.86 & 18.89 & 14.28 & 11.19 & 9.89 \\
\hline Average & 20,28 & 16,74 & 13,83 & 11,13 & 9,78 \\
\hline
\end{tabular}

Source: Research, 2021.

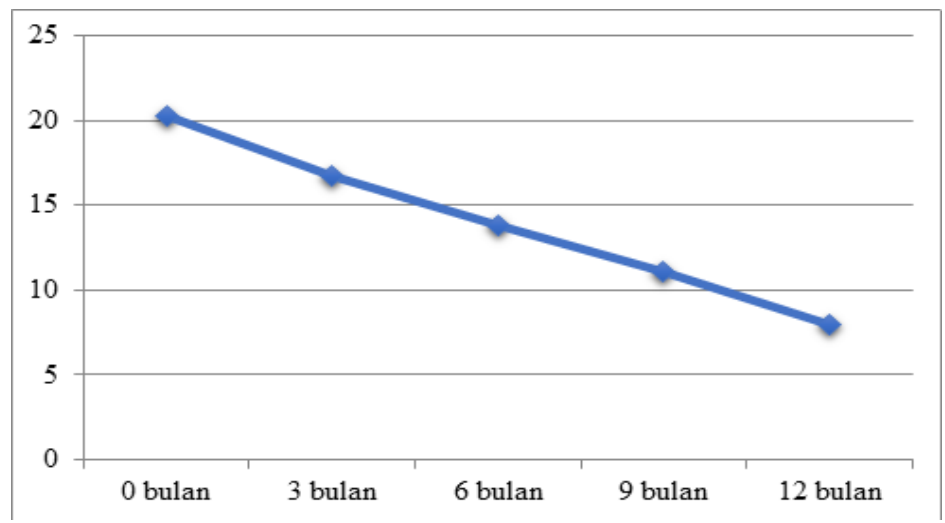

Figure 2 - Graph of Average Value of Breaking Strength (Source: Research, 2021)

The results of the breaking strength test were analyzed with descriptive analysis, and there was a decrease in breaking strength in the nets that have been used. The value of unused nets in breaking strength has the largest value of at least $19.05 \mathrm{Kgf}$ and a maximum of $21.75 \mathrm{Kgf}$. Average of breaking strength value from unused nets obtained $20.28 \mathrm{Kgf}$. Nets that have 3 months of long time of use have a breaking strength value of at least $15.33 \mathrm{Kgf}$ and a maximum of $18.89 \mathrm{Kgf}$ with an average break strength value obtained $16.74 \mathrm{Kgf}$. Nets that have a minimum value of $13.35 \mathrm{Kgf}$ and a maximum of 14.67 with an average of 13.83 Kgf. Nets the length of use 9 months has a minimum value of 10.00 and a maximum of 12.18 $\mathrm{Kgf}$ with an average of $11.13 \mathrm{Kgf}$. Nets that have a minimum length of use 9.03 months and a maximum of $10.65 \mathrm{Kgf}$ with an average of $9.78 \mathrm{Kgf}$.

The value of breaking strength in the net decreases with the length of time using the net. Environmental factors were one of the factors that influence the decrease in the breaking strength. The low value of net breaking strength was caused by the influence of environmental factors such as solar radiation, rainfall, temperature, humidity. The result of the operation time was the increasing frequency of fishing gears affected by air temperature, water, salinity, and friction during pulled fishing gear, pull due to fish movement, and pull due to current or wave. One of the causes of decrease in load breaking was also caused by sunlight. When the net is not operated, the net hangs around on a boat. This makes the net exposed to direct sunlight continuously as similar to the net when operated.

Sunlight exposure directly was also one of the factors that allow the weathering process to occur in inoperable nets or when operated. Sunlight affects the decrease of the breaking strength of a net until the net was damaged; nevertheless, the influence of sunlight on the net when the net was operated was smaller than the drying of the net when it was not operated. According to Klust in Puspito (2009), this is because the iridescent that impacts the sea level is partially reflected by the surface of the water, while the iridescent that penetrates 
the surface of the water is partially absorbed by water particles. Solar radiation decreases as the depth of the water increases, due to the limitations of light penetration when passing through the water. The penetration of ultraviolet light in water with a depth of $1 \mathrm{~m}$ is only $20 \%$ and at a depth of $5 \mathrm{~m}$ is no longer detected.

The increase in the length of time using the net increases the size of the net mesh this leads to a decrease in the effectiveness and productivity of the fishing gear, therefore it is necessary to prove the effectiveness of the length time using purse seine nets. Elongation testing on length time of use was performed using 5 variables. Unused nets were used as control variables and compared to those that have been used for $3,6,9$, and 12 months. Based on the results of the elongation test on the length of use of purse seine nets found in Table 3.

Table 3 - Elongation Results

\begin{tabular}{|c|c|c|c|c|c|}
\hline \multirow{2}{*}{ No } & \multicolumn{5}{|c|}{ Elongation Results (\%) } \\
\cline { 2 - 5 } & Unused & $\begin{array}{c}\text { Age } \\
\text { 3-month }\end{array}$ & $\begin{array}{c}\text { Age } \\
\text {--month }\end{array}$ & $\begin{array}{c}\text { Age } \\
\text { 9-month }\end{array}$ & $\begin{array}{c}\text { Age } \\
\text { 12-month }\end{array}$ \\
\hline 1 & 12.69 & 11.03 & 10.86 & 9.88 & 9.59 \\
\hline 2 & 13.59 & 11.57 & 10.89 & 10.65 & 9.81 \\
\hline 3 & 12.90 & 12.27 & 11.43 & 9.98 & 8.17 \\
\hline 4 & 14.50 & 12.03 & 11.42 & 9.69 & 7.88 \\
\hline 5 & 14.05 & 11.24 & 11.21 & 9.82 & 9.35 \\
\hline 6 & 13.09 & 12.14 & 11.45 & 10.35 & 9.52 \\
\hline 7 & 14.27 & 12.60 & 11.99 & 10.00 & 8.89 \\
\hline 8 & 11.96 & 13.13 & 11.21 & 10.99 & 9.28 \\
\hline 9 & 13.41 & 12.56 & 10.29 & 9.82 & 9.03 \\
\hline 10 & 12.79 & 12.15 & 11.89 & 8.94 & 9.10 \\
\hline Average & 13.32 & 12.07 & 11.26 & 10.01 & 9.06 \\
\hline
\end{tabular}

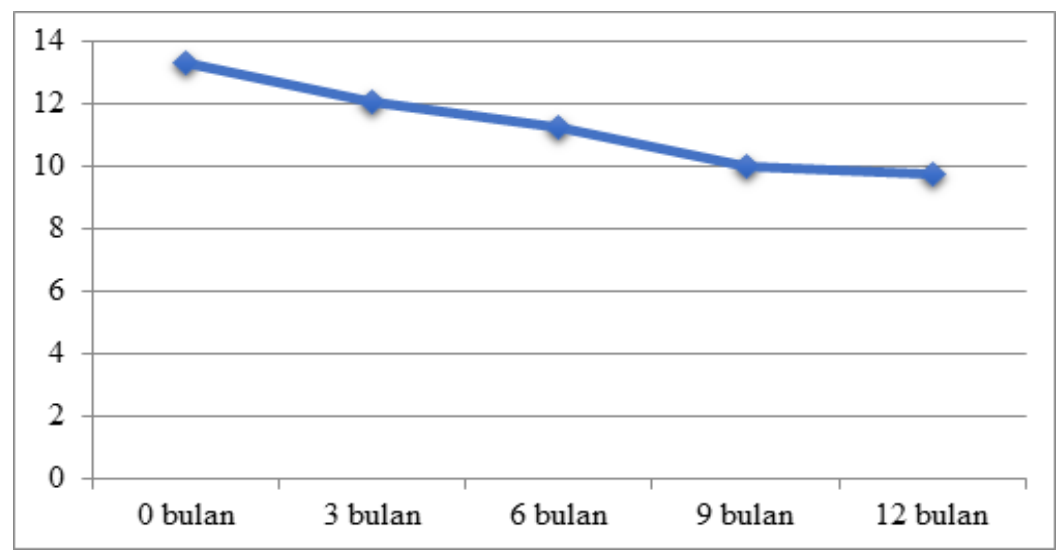

Figure 3 - Graph of Average Elongation Value. Source: Research, 2021

The results of elongation test on length time of use were analyzed with descriptive analysis and it can be known that the longer the use in the net has decreased elongation value. The elongation value of the unused net has an average elongation value of $13.32 \%$. Nets that have 3-months length time of use have an elongation value with an average value of $12.07 \%$. Nets that have 6-months length time of use have an elongation value with an average value of $11.26 \%$. Nets that have 9-months length time of use have an elongation value with an average value of $10.01 \%$, and nets that have 12-months length time of use have an elongation value with an average value of $9.06 \%$. The lowest average elongation value was seen in nets that have been used for 12 months.

Increasing the length of time using the net will also increase the elongation of the mesh size. The increase in the size of the mesh will also have an impact on the increase in the size of the mesh. Fish fiddle and strong and continuous pull is also the cause of the increased part of nets that ensnare fish. Increased elasticity will result in decreased effectiveness and 
productivity of fishing gear. A result of increased mesh elasticity will also cause the main purpose of catching fish to be difficult to catch because the fish can escape through the net mesh.

Physically, nets that endure the elongation will experience a motion and the net will easily break, it is because the increasing length of use in the net also has a smaller value of breaking strength. There is a possibility that elongation will still increase slightly if length time of use increases. According to Nofrizal et. al (2011), that the level of elongation of the net is very closely related to the breaking strength itself. The emulsifier is also related to the level of elongation. Higher the level of elongation or elasticity of the net, the higher breaking strength.

Analyzing the relationship between breaking strength and length time of use the net was conducted with Pearson correlation. The data of breaking strength value was analyzed with the Pearson correlation test and simple regression analysis follow-up test. Previously, the data obtained from the test analysis was first viewed as the distribution of data through normal tests. The results of the breaking strength test have a normal distribution so that further tests can be conducted. Pearson correlation test was a test to find out the relationship between two variables, breaking strength relation, with the length of use. The Pearson correlation test results are in the following Table:

Table 4 - Pearson Breaking Strength Correlation Test Results with Length Time of Use

\begin{tabular}{|c|c|c|c|}
\hline $\begin{array}{c}\text { Breaking Strength (Kgf) } \\
\text { vs } \\
\text { Length Time of Use }\end{array}$ & Correlation Coefficient (r) & P-value & Indication \\
\cline { 2 - 4 } & $-0,932$ & 0.000 & Strong relationship \\
\hline
\end{tabular}

Source: Research, 2021.

The results of the data analysis with the Pearson correlation test showed there was a relationship between breaking strength towards the length time of use of proven nets with $p$ values of $0.000<0.05$. The correlation coefficient between length time of use in the net and breaking strength of -0.932 falls into a fairly strong correlation category. It means there is a strong relationship between breaking strength and length time of net use. The correlation was negative. Negative correlation occurs when changes in one variable are followed by changes in another variable in the opposite direction (inversely proportional). One variable increases, it will be followed by a decrease in the other variable, meaning that if the longer the use of the net it will cause a decrease in the value of the breaking strength and vice versa. The magnitude of the coefficient is expressed by a symbol ( $r$ ) with a coefficient magnitude between -1 to 1 . The closer -1 or 1 the variable correlation the stronger. Conversely, if the correlation coefficient is close to 0 , then the correlation between variables is weaker. Positive and negative signs only indicate the direction of correlation.

The follow-up test is a simple regression analysis that is carried out to find out the influence of the length time of use (independent variable) on the value of the breaking strength of the net (dependent variable). Simple linear regression is used when the dependent variable is influenced by only one independent variable. Based on a simple regression analysis test, the relationship between the length time of the net and the breaking strength of the net is shown in the following Table:

Table 5 - Simple Regression Analysis Test Results Breaking Strength with Length Time of Use

\begin{tabular}{|c|c|c|c|c|c|}
\hline $\begin{array}{c}\text { Breaking Strength (Kgf) } \\
\text { vs } \\
\text { Length Time of Use }\end{array}$ & R Square & Constant Value & Regression Coefficient & Sig & Indication \\
\cline { 2 - 6 } & 0.869 & 21.797 & -2.391 & 0.000 & Big influence \\
\hline
\end{tabular}

Source: Research, 2021.

The results of a simple regression analysis test in the Table above obtained a value of $\mathrm{R}$ Square or.R-2., where $\mathrm{R}$ Square is a value that indicates the percentage of independent variables in influencing dependent variables while the rest is influenced by other variables. The R Square value of 0.869 means the amount of length time of use that affects the 
breaking strength is $86.9 \%$, and the rest is affected by other variables. The regression equation is $Y=21.797-2.391 \mathrm{X}$. Obtaining a constant value of 21,797 means statistically without any length of use $(X)$ then the amount of the value of breaking strength $(Y)$ will increase by 21,797 . Also obtained coefficient value of $-2,391$, coefficient value marked minus, can be said length time of use $(X)$ negatively affects the strength of disconnection $(Y)$. Obtained variable sig value $X$ of $0.000<0.05$, means reject $\mathrm{HO}$ which means $\mathrm{X}$ has a significant effect on $\mathrm{Y}$. Direction or coefficient of regression (b) indicates the increase or decrease of dependent variables. This negative influence means that the decrease in variable $X$ will affect variable $Y$.

Fishermen were used to putting purse seine nets on decks and drying nets in sunlight directly. Ultraviolet (UV) light was a weather factor and has the greatest impact in reducing net breaking strength. It is because UV light can cause the net structure to undergo polymer degradation. Nets placed in the open space experienced the decrease of breaking strength, which will certainly reduce the decrease in the breaking strength of the nets, and also reduce the additional costs that fishermen have to spend to repair the nets. Humidity was also a factor that affects the breaking strength of the net. The higher the humidity, the greater the reduction in net breaking strength. This is because humidity will form pores on the surface of synthetic fibres due to the process of condensation of water. According to Hasly et. al (2017), breaking strength is the maximum strength required for a test that makes the breaking up of materials using tension in kgf units. The proper fishing gear material is a basic material that has a high breaking strength, because the higher the value of breaking strength, the better it will be for fishing gear materials.

Analyzing relationship of elongation with length time of using net used Pearson correlation test. The value of elongation data were analyzed with an analysis tool, Pearson correlation test and a simple regression analysis follow-up test. Previously, the data obtained from the test analysis was first viewed as the distribution of data through normal tests. The results of elongation test data have a normal distribution so that further tests can be performed. Pearson correlation test is a test to determine the relationship between two variables, elongation relationship with length time of the net.

Table 6 - The Results of Pearson Correlation Test

\begin{tabular}{|c|c|c|c|}
\hline $\begin{array}{c}\text { Elongation (\%) } \\
\text { vs } \\
\text { Length Time of Use }\end{array}$ & Correlation Coefficient ( $r)$ & P-value & Indication \\
\cline { 2 - 4 } & $-0,927$ & 0.000 & Strong Relation \\
\hline
\end{tabular}

Source: Research, 2021.

The results of the data analysis with the Pearson correlation test showed there is a relationship between elongation and proven length time of use the net with a p-value of 0.000 $<0.05$. The correlation coefficient between the length time of use net and the elongation value of -0.927 is quite strong, it means that there is a strong correlation between elongation and the length time of use the net and the correlation is negative. Negative correlation occurs when changes in one variable are followed by changes in another variable. One variable increases, it will be followed by a decrease in the other variable, it means that if the longer the use of the net it will lead to a decrease in the value of elongation, and vice versa.

The follow-up test is the simple regression analysis test conducted to determine the influence the length of time using the net (independent variable) has on the elongation value (the dependent variable).

Table 7 - The Results of Simple Regression Analysis Test

\begin{tabular}{|c|c|c|c|c|c|}
\hline $\begin{array}{c}\text { Elongation (\%) } \\
\text { vs } \\
\text { Length Time of } \\
\text { Use }\end{array}$ & $\begin{array}{c}\mathrm{R} \\
\text { Square }\end{array}$ & $\begin{array}{c}\text { Constant } \\
\text { Value }\end{array}$ & $\begin{array}{c}\text { Regression } \\
\text { Coefficient }\end{array}$ & Sig & Indication \\
\cline { 2 - 6 } & 0.860 & 14.323 & $-1,059$ & 0.000 & $\begin{array}{c}\text { A huge influence and } \\
\text { negative }\end{array}$ \\
\hline
\end{tabular}

Source: Research. 2021. 
The results of a simple regression analysis test in the Table above obtained a value of $R$ Square or.R-2., where $R$ Square is a value that indicates the percentage of the length of net usage in affecting the elongation value while the rest is influenced by other variables. $R$ Square obtained a value of 0.860 means the amount of length of use in affecting elongation is $86 \%$ while the rest is influenced by other variables. The regression equation is $Y=14.323$ $-1.059 \mathrm{X}$. Obtaining a constant value of 14,323 means statistically without any length of net usage $(X)$ then the amount of the value of the emulsification $(Y)$ will increase by 14,323 . Obtained coefficient value of long variable usage $(X)$ of $-2,391$. The coefficient value is marked minus, it can be said that the length of net usage $(X)$ negatively affects the value of the emulsifier $(Y)$. Obtained variable sig value $X$ of $0.000<0.05$ means $\mathrm{H} 0$ rejected means there is a significant influence of long use of nets on the elongation value.

The increasing age of usage time of elongation is also decreasing. It can be caused by internal and external forces that work repeatedly when the seine purse mesh is operated. The internal force is caused by the load of the net and its components. External forces are caused by waves and flow. Increasing the usage time causes the size of the net mesh to also change and it allows caught fish to escape the net easily. According to Kusumasteti et.al (2017), the level of multi-time is one of the prerequisites that must be owned by fishing gear materials. Several cases in the process of catching fish by fishing gear are also influenced by the extensibility of the fishing gear itself.

\section{CONCLUSION}

The breaking strength value of multifilament polyamide (PA) nets is lower with the length time of net usage. 3-months of length time of net usage are $16.74 \mathrm{Kgf}, 6$-months has a value of $13.83 \mathrm{Kgf}, 9$-months has a value of $11.13 \mathrm{Kgf}$, and 12 -months has a value of 9.78 Kgf. The elongation value of multifilament polyamide (PA) nets is lower with the length of net usage. 3-months of length time of net usage are $12.07 \%, 6$-months have a value of $11.26 \%$, 9-months have a value of $10.01 \%$, and 12 -months have a value of $9.06 \%$. There is a strong relationship between the length time of net usage and the value of breaking strength, while the regression hypothesis shows a significant influence between the braking power and the length of use of Polyamide Nets (PA) Multifilament Size 210D/15 X 3/4 Inch. This means that the increasing use of the net will affect the decrease in the breaking strength value. There is a strong relationship between the length time of net usage and the value of the emulsification, while the regression hypothesis shows a significant influence between elongation to the length of use of Polyamide Nets (PA) Multifilament Size 210D/15 X 3/4 Inch. This means that the increasing length time of net usage in the net will affect the decrease elongation.

\section{REFERENCES}

1. Al-Oufi, H., E. Mclean, A. S. Kumar, M. Claereboudt and M. Al-Habsi. 2003. The Effects of Solar Radiation upon Breaking Strength and Elongation of Fishing Nets. Fisheries Reasearch. 6 (6): 115-119.

2. Ardidja, S. 2010. Bahan Alat Penangkap Ikan. STP Press. Edisi I. Jakarta. $192 \mathrm{HIm}$.

3. Arifin, S., A. Brown and Bustari. 2015. Differential Diameter Size of Pvc Trap To Catch Fish On Public Water In Bungaraya Village Siak District Riau Province. 2 (4):1-12.

4. Armita, R. F. 2017. Studi Perubahan Panjang Benang Jaring Dari Bahan PE (Polyethylene) Yang Direndam Dalam Air Laut and Air Tawar. 9 (4): 1-14.

5. Ayodhyoa, A. U. 1981. Metode Penangkapan Ikan. Yayasan Dewi Sri: Bogor.

6. Brandt AV. 1984. Fish Catching Methods of the World. 3 Rd Edition. Farnham, England (GB): Fishing News Books Ltd. 418 Pp

7. Eyo, J. E. and Akpati, C. I. 1995. Fishing Gears and Fishing Methods. Fisheries and Hydrologi Research. 1 (1): 143-159.

8. Hadi, S, R. N. A. Takwin, and A. Dani. 2016. Uji Kekuatan Tekan and Kekuatan Lentur Pipa Air Pvc. Jurnal Logic., 16(1): 7-13. 
9. Hawari, D. 2019. Sintesis and Karakterisasi Polipaduan Poli Asam Laktat (Pla) and Poli E-Kaprolakton (Pcl) Sebagai Bahan Baku Pembuatan Benang Bedah Operasi Dengan Emulsifier Gelatin. [Skripsi]. Fakultas Matematika and Ilmu Pengetahuan Alam Universitas Lampung, Lampung $74 \mathrm{HIm}$.

10. Himelda, E. S. Wiyono, A. Purbayanto, and Mustaruddin. 2012. Seleksi Jenis Alat Tangkap and Teknologi Yang Tepat Dalam Pemanfaatan Sumberdaya Lemuru Di Selat Bali. BULETIN PSP. 20(1): 89-102.

11. Irsyadi, T., Isnaniah, and Syofyan, I. 2015. Study On Strength Broke and Elongation Yarn Polyamide (PA) With The Addition of Skin Stem Extract Salam (Syzygium Polyanthum), Extract Leather Trunk Jengkol (Archidendron Pauciflorum) and Extract Leather Trunk Guava (Psidium Guajava). Jurnal Online Mahasiswa Fakultas Perikanan and IImu Kelautan Universitas Riau. 1 (1): 1-11.

12. Iskandar M. D, and A. P. Prasetyo. 2010. Breaking Strength Benang Pa Multifilamen 210d/6 Pada Penyimpanan Di Ruang Terbuka. Bawal: 3(1): 57-63.

13. Iskandar, Mokhamad Dahri, and Andhika Prima Prasetyo.2017. "Breaking Strength Benang Pa Multifilamen 210d/6 Pada Penyimpanan Di Ruang Terbuka." Bawal Widya Riset Perikanan Tangkap 3.1: 57-63.

14. Isnaniah, Isnaniah, and Nofrizal Nofrizal. 2015. "Study on Strength Broke (Breaking Strength) and Elongation (Elongation) Yarn PA (Polyamide) With Addition of Skin Stem Extract Salam (Syzygium Polyanthum) With Different Concentration." Jurnal Online Mahasiswa Fakultas Perikanan and IImu Kelautan Universitas Riau 2.1: 1-12.

15. Jannah, I. R., Pramitasari, S. D., \& Setiyanto, I. (2017). Pengaruh Perendaman Air Tawar and Air Laut Terhadap Nilai Kekuatan Putus (Breaking Strength) and Kemuluran (Elongation) Pada Benang Polyamide (Pa) Monofilamen Diameter $0.4 \mathrm{Mm}$. Jurnal Perikanan Tangkap: Indonesian Journal of Capture Fisheries, 1(02).

16. Kim, S., Kim, P., Lim, J., An, H., \& Suuronen, P. (2016). Use of Biodegradable Driftnets To Prevent Ghost Fishing: Physical Properties and Fishing Performance For Yellow Croaker. Animal Conservation, 19(4), 309-319.

17. Klust, G. 1987. Bahan Jaring Untuk Penangkakpan Ikan. Diterjemahlan Oleh Tim BPPI Semarang. Edisi 2. Bagian Proyek Pengembangan Teknik Penangkapan Ikan. Balai Penangkapan Ikan. Semarang. $188 \mathrm{Hal}$.

18. Kusumasteti, E., Sardiyatmo, S., \& Kurohman, F. (2017). Analisis Pengaruh Perbedaan Perendaman Mata Jaring Polyamide (Pa) Monofilamen No. 35mesh Size 3, 5 Inch Pada Air Tawar, Air Laut and Solar Terhadap Kekuatan Putus (Breaking Strength) and Kemuluran (Elongation). Journal of Fisheries Resources Utilization Management and Technology, 6(4), 20-29.

19. Mainnah, Muth. Diniah and Budhi Hascaryo Iskandar. Perpaduan Serat Daun Nanas (Ananas Comosus) and Kitosan Sebagai Material Alat Penangkapan Ikan Ramah Lingkungan.Marine Fisheries: Journal of Marine Fisheries Technology and Management 7.2 (2016): 149-159.

20. Muntaha, A., Soemarmo, S. Muhammad, and S. Wahyudi. 2013. Kajian Kecepatan Kapal Purse Seiner Terhadap Hasil Tangkapan Ikan Di Perairan Probolinggo. Jurnal Kelautan. 6(1): $7 \mathrm{HImn}$.

21. Muntaha, A., Soemarno, S., Muhammad, S., \& Wahyudi, S. (2013). Kajian Kecepatan Kapal Purse Seiner Terhadap Hasil Tangkapan Ikan Di Perairan Probolinggo. Jurnal Kelautan: Indonesian Journal of Marine Science and Technology, 6(1), 29-35.

22. Murdani, A., Isnaniah, and Nofrizal. 2015. The Effect of Drying For The Breaking Strength of Polyamide Yarns Which Hava Experienced The Preservation of Jengkol Bark Extract (Archidendronpaucifiorum) and Salam Bark Extract (Syzygium Polyanthum). Jurnal Online Mahasiswa Fakultas Perikanan and IImu Kelautan Universitas Riau. 1 (1): 1-13.

23. Murdani, A., Isnaniah, I., \& Nofrizal, N. (2014). The Effect of Drying For The Breaking Strength of Polyamide Yarns Which Hava Experienced The Preservation of Jengkol Bark Extract (Archidendronpaucifiorum) and Salam Bark Extract (Syzygium Polyanthum) (Doctoral Dissertation, Riau University).

24. Nofrizal, N., Ahmad, M., Syofyan, I., \& Habibie, I. (2011). Kajian Awal Pemanfaatan 
Rumput Teki (Fimbristylis Sp), Linggi (Penicum Sp) and Sianik (Carex Sp) Sebagai Serat Alami Untuk Bahan Alat Penangkapan Ikan. Jurnal Natur Indonesia, 14(1), 100-106.

25. Nugraha, A., B.A. Wibowo and Asriyanto. 2014. Analisis Finansial Usaha Perikanan Tangkap Purse Seine Di Pelabuhan Perikanan Pantai (PPP) Tasik Agung Kabupaten Rembang. Journal of Fisheries Resources Utilization Management and Technology. 3(4): 56-65.

26. Prasetyo, A. P. and M. D. Iskandar. 2010. Breaking Strength Jaring Polyamide Mulltifilamen 210D/6 Pada Penyimpanan Di Ruang Terbuka and Tertutup: Aspek Teknis Perikanan Payang Di Teluk Pelabuhan Ratu. 16(3): 173-183.

27. Pratama, M. A. D., Hapsari, T. D., \& Triarso, I. (2016). Faktor-Faktor Yang Mempengaruhi Hasil Produksi Unit Penangkapan Purse Seine (Gardan) Di Fishing Base Ppp Muncar, Banyuwangi, Jawa Timur Factors Affecting The Production of Purse Seine Unit In Fishing Base Muncar Fishing Port Banyuwangi, East Java. Saintek Perikanan: Indonesian Journal of Fisheries Science and Technology, 11(2), 120-128.

28. Pratama, M. A. D., T. D. Hapsari and I. Triarso. 2016. Faktor-Faktor Yang Mempengaruhi Hasil Produksi Unit Penangkapan Purse Seine (Gardan) Di Fishing Base PPP Muncar, Banyuwangi, Jawa Timur. Jurnal Saintek Perikanan. 11(2): 120-128.

29. Puspito, G. (2009). Perubahan Sifat-Sifat Fisik Mata Jaringan Insang Hanyut Setelah Digunakan 5, 10, 15, and 20 Tahun. Jurnal Penelitian Sains, 12(3).

30. Rahmadhani, Tri, Irwandy Syofian, and Polaris Nasution. "Study of The Change Polyamide (PA) Net Yarn Immersion In Fresh Water and Sea Water." Jurnal Online Mahasiswa Fakultas Perikanan and IImu Kelautan Universitas Riau 4.2: 1-12.

31. Rambun P, A., Sunarto and I. Nurruhwati. 2016. Selektivitas Alat Tangkap Purse Seine Di Pangkalan Pendaratan Ikan (PPI) Muara Angke Jakarta. Jurnal Perikanan Kelautan. 7(2): 97-102.

32. Ramos, J. M. L.1999. Chemical and Physical Properties of Synthetic Fibres Most Commonly Used In Fishing Gear, With Reference To Their Use In Cape Verde Fisheries. Fisheries Training Programme. 1(1): 1-26.

33. Sari, Velysiana Ayunda Puspita, Herry Boesono, and Indradi Setiyanto. 2017."Analisis Pengaruh Media Perendaman Benang PA Multifilamen D21 Terhadap Kekuatan Putus (Breaking Strength) and Kemuluran (Elongation) Dengan Metode Sni Iso 1805: 2010." Journal of Fisheries Resources Utilization Management and Technology 6.4: 168-174.

34. Sitorus, H. F., Bambang, A. N., \& Jayanto, B. B. (2017). Analisis Aspek Teknis and Kelayakan Usaha Perikanan Purse Seine Di Tpi Pelabuhan, Kota Tegal. Jurnal Perikanan Tangkap: Indonesian Journal of Capture Fisheries, 1(02).

35. Sitorus, H. F., Bambang, A. N., \& Jayanto, B. B. (2017). Analisis Aspek Teknis and Kelayakan Usaha Perikanan Purse Seine Di Tpi Pelabuhan, Kota Tegal. Jurnal Perikanan Tangkap: Indonesian Journal of Capture Fisheries, 1(02).

36. Standar Nasional Indonesia. 2010. SNI ISO 1806:2010, Alat Penangkapan Ikan Berbahan Jaring - Penentuan Gaya Putus Mata Jaring. BSNI, Jakarta.

37. Suhana, N and A. Sugriana. 2016. Pengaruh Nilon Monofilament Pada Campuran Beton Terhadap Kuat Tekan and Kuat Lentur. Jurnal Rekayasa Infrastruktur., 1(3): 106-162.

38. Suhartono, Haruna, and J. B. Pailin. 2013. Identifikasi and Prediksi Daerah Penangkapan Ikan Kembung (Rastrelliger Spp) Di Perairan Kabupaten Pangkep. Jurnal "Amanisal" PSP FPIK Unpatti-Ambon. 2(2): 55-65.

39. Suryana, S.A., I.P. Rahardjo and Sukandar. 2013. Pengaruh Panjang Jaring, Ukuran Kapal, PK Mesin, and Jumlah ABK Terhadap Produksi Ikan Pada Alat Tangkap Purse Seine Di Perairan Prigi Kabupaten Trenggalek Jawa Timur. PSPK Journal. 1(1): 36-43.

40. Syarif, Baithur and Hudring. 2012. Pukat Cincin (Purse Seine). Balai Besar Penangkapan Ikan: Semarang.

41. Widiartha, I.G. N. H Sari, Sujita. 2012. Study Kekuatan Bending and Struktur Mikro Komposit Polyethylene Yang Diperkuat Oleh Hybrid Serat Sisal and Karung Goni. Dinamika Teknik Mesin, 2(2): 92-99.

42. Zarochman and A. Wahyono. 2005. Pukat Cincin (Purse Seine). Balai Besar Pengembangan Penangkapan lkan: Semarang. 